\title{
Perceptions of traders and manufacturers towards GST
}

\author{
Sanjay Nandal ${ }^{1}$, Diksha $^{2, *}$ \\ ${ }^{\mathbf{1}}$ Assistant Professor, ${ }^{2}$ Research Scholar, Institute of Management Studies and Research, Maharshi Dayanand University, Rohtak, \\ Haryana, India
}

*Corresponding Author:

Email: dikshakhera4@gmail.com

\begin{abstract}
GST is a value-based indirect tax which levied on the value added by the supplier. GST has been introduced in more than 160 countries and France was the first to introduce in 1954. In India GST is implemented from 1 $1^{\text {st }}$ July 2017 with motto of "one nation, one market and one tax". In Indian taxation history, the introduction of GST brought the revolutionary changes which subsumed all the multiple indirect taxes under a single umbrella. The purpose of present study is to investigate the perceptions of traders and manufacturers towards GST, their satisfaction level from GST's implementation and significant differences between their perceptions and satisfaction. This study has conducted particularly in three regions i.e. Rohtak, Gurgaon and Faridabad of Haryana state and total 200 respondents were selected on the random sampling basis and t-test was used. The results of the study conclude that $73 \%$ of respondents are satisfied from GST's implementation. This study suggests for successful implementation of GST, government should organize the awareness and training programs to increase the GST knowledge, reduce the technical error of GSTN, expand the digital infrastructure, properly check whether the benefits of reduced cascading effect is passing to end customer or not and reduce the return filing formalities.
\end{abstract}

Keywords: GST (Goods and Services tax), VAT (Value added tax), CGST (central Goods and services tax), GSTN (goods and services tax network), ITC (Input Tax Credit).

\section{Introduction}

GST (Goods and Services tax) is a value-based tax which levied on the value added by the supplier at the time of supply of goods or services (Padmashree, 2010). In India, GST is implemented w.e.f. $1^{\text {st }}$ July 2017 with the motive of transforming the Indian economy as a "one nation, one market and one tax". In Indian taxation history, the implementation of GST brought the revolutionary changes because this broadbased comprehensive tax subsumed all those indirect taxes or surcharges which were levied on the supply of goods or services before the $1^{\text {st }}$ July 2017 in a single customized umbrella (Aggarwal, 2017, pp 1). This eliminates the multiple indirect taxes or surcharges like Central sales tax, VAT, services tax, central excise duty, purchase tax, luxury tax etc. Our Honorable Prime Minister Narendra Modi recognized the GST not only as Goods and Services tax but also as a "Good and simple tax". GST is a destination-based consumption tax which will be collected by the state government of that particular state where the goods or services are actually consumed. In India the dual model of GST is adopted where the both central and state government had the power to levy the GST. This dual model of GST is also followed in Brazil and Canadian economy. GST is like a substitute of VAT because both are charged on the value added by the supplier (Kumar \& Ashwini 2017). But the GST is the further improvement of VAT because in VAT framework, different tax rates were charged in the different states at the same goods which complicates the doing business in different states and in GST framework there is same tax rates charge across the all states of nation. The introduction of GST transformed the India as a common economic market and ease the doing business in India where is no any barrier on the movement of goods or factors of production in different states in the form of entry tax, octroi, purchase tax, luxury tax etc.

\section{The GST framework made on the three principles: \\ 1. Welfare of the poor people \\ 2. Neutrality of government revenue \\ 3. No excessive burden on a single sector. \\ In GST framework, CGST, SGST, IGST is levy.}

In GST framework, the tax credit is allowed on the input tax paid at each stage of value-chain starting from the manufacturer level to the retailer level thereby taxing only the value added by the supplier. The tax credit of GST paid on the purchase of input may be use against the GST payable on the supply of goods or services. The availability of input tax credit mechanism in GST framework eliminated the cascading effect of taxation/double taxation. Thus customers pay only the GST charge by the last supplier in value-chain through setting off the benefits of tax paid in previous stage of value-chain. This will help to reduce the prices of goods or services. Let's take one example to show how the prices will reduce under the GST regime: 


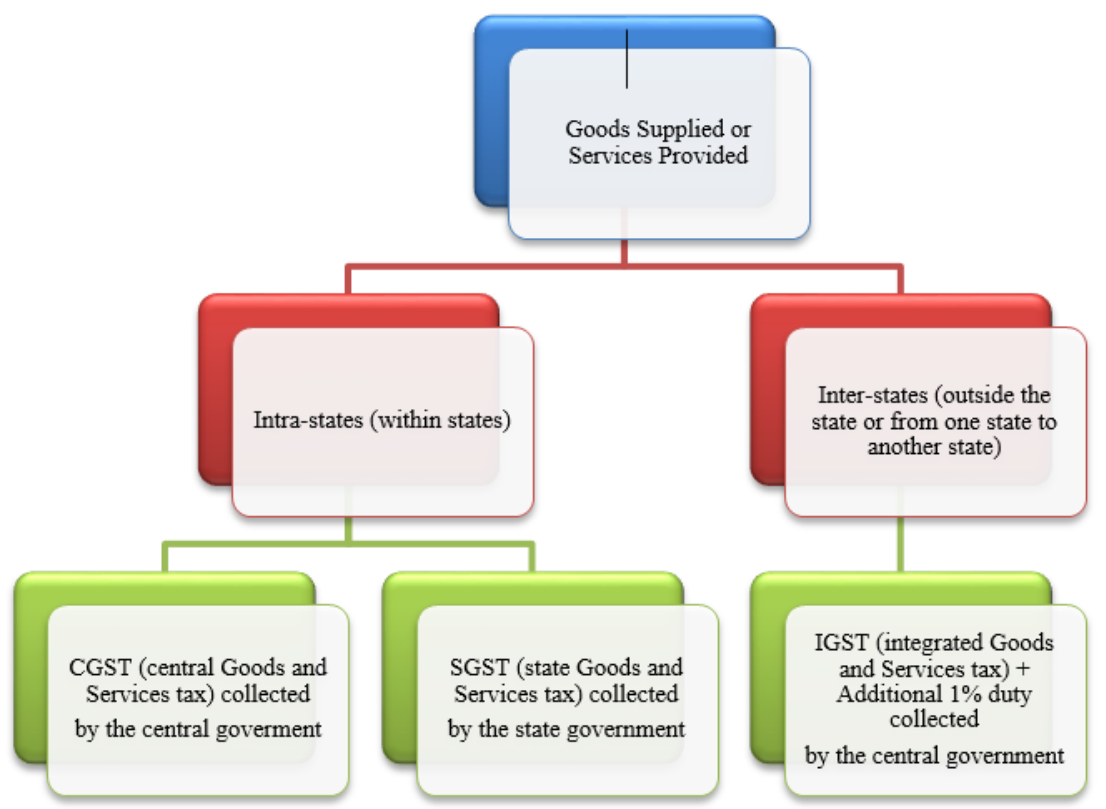

Fig. 1: Structure of goods and services tax

Table 1: Prices before and after GST

\begin{tabular}{|c|c|c|}
\hline (A) Manufacturer to Wholesaler & Without GST (Rs) & With GST (Rs) \\
\hline Cost of productions & 5000 & 5000 \\
\hline+ Profit & 2000 & 2000 \\
\hline Manufacture Price & 7000 & 7000 \\
\hline + Excise duty $12 \%$ & $7000 * 12 \%=840$ & \\
\hline Total (a) & 7840 & 7000 \\
\hline VAT 6\% (b) & $7840 * 6 \%=470.40$ & \\
\hline $\begin{array}{l}\text { GST } 18 \%(\mathrm{c}) \\
\text { (1) } \text { CGST 9\% } \\
\text { (2) } \text { SGST 9\% }\end{array}$ & - & $\begin{array}{l}7000 * 9 \%=630 \\
7000 * 9 \%=630\end{array}$ \\
\hline Invoice Value $(\mathrm{a}+\mathrm{b}+\mathrm{c})$ & 8310.40 & 8260 \\
\hline \multicolumn{3}{|l|}{ (B) Wholesaler to Retailer } \\
\hline Cost of goods to wholesaler & $\begin{array}{l}7840 \text { (due to the ITC of VAT } \\
\text { from the government) }\end{array}$ & $\begin{array}{c}7000 \text { (due to the ITC of CGST and } \\
\text { SGST) }\end{array}$ \\
\hline + Profit $10 \%$ & 784 & 700 \\
\hline Total value (a) & 8624 & 7700 \\
\hline+ VAT $6 \%(b)$ & $8624 * 6 \%=517.44$ & $\bar{L}$ \\
\hline $\begin{array}{l}\text { + GST 18\% (c) } \\
\text { (1) CGST 9\% } \\
\text { (2) SGST 9\% }\end{array}$ & 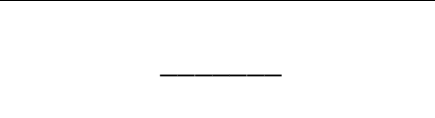 & $\begin{array}{l}7700 * 9 \%=693 \\
7700 * 9 \%=693\end{array}$ \\
\hline Invoice Value $(\mathrm{a}+\mathrm{b}+\mathrm{c})$ & 9141.44 & 9086 \\
\hline \multicolumn{3}{|l|}{ (C) Retailer to consumer } \\
\hline Cost of goods to retailer & $\begin{array}{l}8624 \text { ( due to the ITC of VAT } \\
\text { from the government) }\end{array}$ & $\begin{array}{l}7700 \text { (due to the ITC of CGST and } \\
\text { SGST from the government) }\end{array}$ \\
\hline+ Profit $10 \%$ & 862.4 & 770 \\
\hline Total Value (a) & 9486.40 & 8470 \\
\hline +VAT 6\% (b) & $9486.40 * 6 \%=569.184$ & \\
\hline $\begin{array}{l}\text { + GST 18\% (c) } \\
\text { (1) CGST 9\% } \\
\text { (2) SGST 9\% }\end{array}$ & $\ldots$ & $\begin{array}{l}8470 * 9 \%=762.3 \\
8470 * 9 \%=762.3\end{array}$ \\
\hline Total Price to consumer $(a+b+c)$ & 10055.584 & 9994.6 \\
\hline
\end{tabular}

Price reduced in GST regime $=10055.584-9994.6=$ Rs 60.984 
This price reduction will benefit the final consumer and they will only pay the tax charge by last supplier of the value-chain. The total input tax credit available to the different suppliers

Table 2: ITC available before and after GST

\begin{tabular}{|l|c|c|}
\hline Input Tax credit (ITC) available to: & Without GST & With GST \\
\hline Wholesaler & Rs 470.40 & Rs 1260 \\
\hline Retailer & Rs 517.44 & Rs 1386 \\
\hline
\end{tabular}

Table 1 and Table 2 show how the prices reduced and ITC increased after the GST's implementation. The implementation of GST has impacted almost each and every sector of economy but the objective of present article is to investigate the perceptions of traders and manufacturers towards GST and their satisfaction from GST's implementation.

\section{Review of Literature}

Breen, Bergin-Seers, Roberts \& Sims (2002) this study examines the impact of the introduction of the Goods and Services Tax (GST) on small business in Australia in the context of the experiences faced in similar countries overseas. Using a case study methodology, data was gathered from six small businesses that were observed throughout the introductory period of the new tax system. In particular, this article considers the costs for small businesses in complying with the new tax system. Businesses reported actual GST compliance costs ranging from $\$ 3,331$ to $\$ 30,140$ per business in the cases examined. For the two smallest businesses, their compliance costs amounted to over $3 \%$ of the firm's reported annual turnover. The study also identified significant changes in on-going record keeping and accounting costs that are required by small businesses in order to meet their GST obligations. These findings indicate that governments need to be more aware of the impact of tax reforms on small businesses if they wish to implement changes with minimal adverse impacts on business operations. The study revealed that four of the six businesses reported cash flow problems that they believed were caused in some way by the GST. Two of them partly blamed slower conditions in their industry. Their debtors were slow in paying, causing the businesses to increase their overdraft. Business operators lacked the time and energy to seek new business opportunities.

Spiro, P. (1993) wrote about the Post-GST increase in underground economy in Canada since the introduction of GST in 1991 on the basis of experiences of other developing countries. He states that there is maximum likelihood that at margin switching from the narrow- based federal manufacturers' sales tax to broad-based GST may have increase the incentives and opportunities for tax evasion. He states that evasion of VAT or GST is the significant problem at the retail level. He analyzed the growth in cash balance held by public and change in transactions volume which provided the avenues for estimating the substantial increase in underground economy in Canada since introduction of GST. He said the GST would not increase the tax reporting because the enterprises already demanded the tax invoice from its suppliers for income tax documentation purpose. He stated that the GST will push the tolerance level of taxpayer who already annoyed with high rates of corporate tax, to the point where they will avoid it in large retailer level because government avoids in most of the cases to administer the tax compliance of small level retailer due to the high cost in compare of benefits. Retailers claim their whole input tax credit against the portion of sale that they do report, and they do not lose any input tax credit through GST evasion.

Rametse, N. \& Pope, J. (2012) analyzed the economic impact of GST on small businesses in Western Australia, particularly their start-up compliance costs such as cost of equipment, professional accounting and IT consultancy fees, training course fees and time costs. The conclusion of study states that it was costly for small businesses in preparing to comply with the GST requirements but if the size of businesses increases, GST startup costs decrease as a percentage of turnover. They also states that small businesses management and efficiency may improve as a result of investment in IT, better accounting record keeping from GST implementation.

Huang \& Liu (2009) analyzed the impact of GST on banking mortgage costs in Australia after the GST implementation. The key findings of this study are that the introduction of the GST in July 2000 has contributed to significant rises in mortgage costs charged by banks in the post-GST periods on the basis of t-test and multivariate regression results

Aggarwal, K. (2017) analyzed the perception of business and salaried people about GST in Agra region. The responses of people collected by the use of Likertscale and people were selected on the basis of judgement sampling and data analysis tools of mean and one sample T-test used to analyze the perceptional data. The author concluded on the basis of significant perceptions of respondents that GST has increased the legal compliances, increased the tax burden on businesses, badly impacting the small businesses, GST will increase the inflation (prices) in the country, GST is a very good tax reform for India, GST is beneficial in long-term and GST will increase the tax collection of the government

Barhate (2017) found that people have no doubt whatsoever regarding the proposed benefits of GST 
irrespective of their business type, legal status of business for the reason being they feel irritated by the present system which appears to be cumbersome. Most respondents believe that GST will bring monetary gains to their business, uniformity of tax rates will decrease the material costs, check the tax evasion, improve the refund procedure and accounting procedure, improve the transparency in tax system, evade the cascading effect of taxation and do not anticipate any significant boost in tax compliance costs. Interestingly, respondents expect the spending on tax compliance to go down after GST is implemented. The lack of information coupled with the apathy towards reforms may paralyze the speedy implementation of this system especially in small towns where still not a single orientation programs have been planned and executed till date by competent authorities.

Zainol \& Soon (2016). This study investigated the opportunities and challenges faced by the Malaysian SMEs with the introduction of GST and found the significantly increase in compliance cost and record maintenance and tax collection work become so tedious as well as expensive.

Chouhan (2017). The author investigated the awareness level of small business owners about GST in Rajasthan state and difficulties they faced from GST's implementation. The study concluded that there is lack of awareness about GST and its rules.

\section{Materials and Methods}

The present research is exploratory in nature. Since GST is new phenomenon in India and few studies had conducted on the perceptions of traders and manufacturers towards GST after its implementation.

\section{Objectives of the study}

1. To study the perceptions of the traders and manufacturers in Rohtak, Gurgaon and Faridabad regions of Haryana state towards GST.

2. To study the satisfaction level of traders and manufacturers in Rohtak, Gurgaon and Faridabad regions of Haryana state from newly implemented tax regime.

Sample Design: This study has been conducted particularly in Rohtak, Gurgaon and Faridabad regions of Haryana state and total 200 respondents were selected for sample size on the random sampling basis. The data was collected from the primary sources of field survey of traders and manufacturers.

Method of Data Collection: To collect the responses, a structured questionnaire was used. The responses were collected from respondents using the 5-point Likert scale from strongly disagree (1 point) to strongly agree (5 point).

Research Tool: The data analysis tool of mean statistic to study the perception of traders and manufacturers towards GST and their satisfaction from GST, independent sample T-test to investigate the significant difference between their perceptions and satisfaction were used. Before applying the T-test, reliability analysis had been done for internal consistency of scale. The cronbach's alpha coefficient of construct "GST's benefits" was .956 and of construct "GST's challenges" was .760 which is acceptable before applying any research tool.

\section{Hypotheses}

1. H1: There is significance difference between the perceptions of traders and manufacturers towards GST.

2. H2: There is significant difference between satisfaction of Traders and manufacturers from GST's implementation.

\section{Analysis}

This section involves three sub-sections one for nature of the business, second for perceptions of traders and manufacturers towards GST and significant differences between perceptions and third for satisfaction of traders and manufacturers from GST's implementation and significant differences between satisfaction.

\section{Nature of the business}

Table 3: Nature of the business

\begin{tabular}{|l|c|c|}
\hline $\begin{array}{c}\text { Nature of the } \\
\text { business }\end{array}$ & No of firms & Percentage \\
\hline Manufacturing & 96 & $48 \%$ \\
\hline Trading & 104 & $52 \%$ \\
\hline Total & 200 & $100 \%$ \\
\hline
\end{tabular}

Source: field survey

After the data analysis it was found that $48 \%$ of respondents were manufacturers and $52 \%$ of respondents were traders and concluded that the trading firms were more than the manufacturing firms in the study area on the basis of results of data analysis.

Perceptions of Traders and Manufacturers towards GST: This section presents the perceptions of traders and manufacturers towards GST and the significant differences between their perceptions.

Table 4: Perceptions of traders and manufacturers towards GST

\begin{tabular}{|l|c|}
\hline \multicolumn{1}{|c|}{ Statements } & $\begin{array}{c}\text { Overall Mean } \\
\mathbf{N = 2 0 0}\end{array}$ \\
\hline GST has reduced the cascading effect of taxation & 4.0800 \\
\hline GST has reduced the time in delivery of goods & 3.7200 \\
\hline
\end{tabular}




\begin{tabular}{|l|c|}
\hline GST will check the tax evasion & 3.2800 \\
\hline GST has ease the doing business in India & 3.3300 \\
\hline GST has reduced the material costs & 2.6650 \\
\hline GST's implementation will expand the market of your business & 3.8900 \\
\hline GST will boost the mission of "Make in India" campaign & 4.0950 \\
\hline GST facilitates the ease in compliance in compare of previous indirect tax regime & 2.6900 \\
\hline GST improved the transparency in taxation system and prices & 3.0600 \\
\hline GST transformed the Indian economy as a common economic market & 4.2500 \\
\hline $\begin{array}{l}\text { GST will give the managerial benefits due to proper accounting record maintenance for legal } \\
\text { compliances }\end{array}$ & 4.1450 \\
\hline GST will give the benefits in long run & 4.3850 \\
\hline GST will broaden the tax base & 3.5700 \\
\hline GST will improve the exports of the country & 3.6450 \\
\hline GST is complex to understand & 4.5150 \\
\hline GST has increased the inflation in country & 3.7700 \\
\hline GST has increased the tax burden on the businessman & 4.1200 \\
\hline GST has increased the compliance costs & 4.2450 \\
\hline In GST return filing formalities is too tedious & 4.4450 \\
\hline GST has increased the accounting record maintenance work & 4.6382 \\
\hline GST has increased the investment in working capital & 4.0650 \\
\hline The motto of GST "one nation and one tax" is only a illusion & 4.4400 \\
\hline $\begin{array}{l}\text { GSTN has too many technical problems and further difficult the return filing and getting ITC } \\
\text { on proper timing }\end{array}$ & 4.5100 \\
\hline GST is affecting the business very badly & 2.8200 \\
\hline GST will be helpful in overall development of economy & 4.1800 \\
\hline GST has improved the profitability of your business & 2.5950 \\
\hline overall satisfaction from GST & 3.6450 \\
\hline & \\
\hline
\end{tabular}

Source: field survey

Table 4 presents the perceptions of traders and manufacturers towards GST and most important point come out after the analysis that GST has increased the accounting record maintenance work with mean value of 4.63 and followed by GST is complex to understand with mean value of 4.51 , GSTN has too many technical problems with mean value of 4.51 and in GST return filing formalities is too tedious with mean value of 4.445. The other important fact of perceptions towards GST which has come out after analysis that GST will be beneficial in long run with mean value of 4.38 and
GST has transformed the Indian economy in a common market with mean value of 4.25 .

To check the significant differences between the perceptions of traders and manufacturers the following null and alternate hypothesis was developed

H0: There is no significant difference between the perceptions of traders and manufacturers towards GST

H1: There is significant difference between the perceptions of traders and manufacturers towards GST

The significance of developed hypothesis was tested with the help of independent sample t-test'

Table 5: Independent samples $t$ test

\begin{tabular}{|c|c|c|c|c|c|c|c|c|c|c|}
\hline \multirow{3}{*}{\multicolumn{2}{|c|}{$\begin{array}{l}\text { Perceptions of traders and } \\
\text { manufacturers towards GST }\end{array}$}} & \multicolumn{2}{|c|}{$\begin{array}{c}\text { Levene's } \\
\text { Test for } \\
\text { Equality of } \\
\text { Variances } \\
\end{array}$} & \multicolumn{7}{|c|}{ t-test for Equality of Means } \\
\hline & & \multirow[t]{2}{*}{$\mathrm{F}$} & \multirow[t]{2}{*}{ Sig. } & \multirow[t]{2}{*}{$\mathrm{T}$} & \multirow[t]{2}{*}{ Df } & \multirow[t]{2}{*}{$\begin{array}{l}\text { Sig. (2- } \\
\text { tailed) }\end{array}$} & \multirow[t]{2}{*}{\begin{tabular}{|c|} 
Mean \\
Difference
\end{tabular}} & \multirow[t]{2}{*}{$\begin{array}{l}\text { Std. Error } \\
\text { Difference }\end{array}$} & \multicolumn{2}{|c|}{$\begin{array}{l}\text { 95\% Confidence } \\
\text { Interval of the } \\
\text { Difference } \\
\end{array}$} \\
\hline & & & & & & & & & Lower & Upper \\
\hline \multirow{2}{*}{$\begin{array}{l}\text { S1: GST has } \\
\text { reduced the } \\
\text { cascading effect } \\
\text { of taxation }\end{array}$} & $\begin{array}{l}\text { Equal variances } \\
\text { assumed }\end{array}$ & 3.031 & .083 & -.874 & 198 & .383 & -.13381 & .15315 & -.43582 & .16820 \\
\hline & $\begin{array}{l}\text { Equal variances } \\
\text { not assumed }\end{array}$ & & & -.867 & 184.957 & .387 & -.13381 & .15430 & -.43823 & .17060 \\
\hline $\begin{array}{l}\text { S2: GST has } \\
\text { reduced the time }\end{array}$ & $\begin{array}{l}\text { Equal variances } \\
\text { assumed }\end{array}$ & 10.208 & .002 & .651 & 198 & .516 & .11779 & .18095 & -.23904 & .47462 \\
\hline
\end{tabular}




\begin{tabular}{|c|c|c|c|c|c|c|c|c|c|c|}
\hline $\begin{array}{l}\text { in delivery of } \\
\text { goods }\end{array}$ & $\begin{array}{l}\text { Equal variances } \\
\text { not assumed }\end{array}$ & & & .655 & 196.884 & .513 & .11779 & .17982 & -.23684 & .47242 \\
\hline \multirow{2}{*}{$\begin{array}{l}\text { S3: GST will } \\
\text { check the tax } \\
\text { evasion }\end{array}$} & $\begin{array}{l}\text { Equal variances } \\
\text { assumed }\end{array}$ & 14.283 & .000 & -.833 & 198 & .406 & -.11779 & .14140 & -.39663 & .16106 \\
\hline & $\begin{array}{l}\text { Equal variances } \\
\text { not assumed }\end{array}$ & & & -.825 & 180.142 & .410 & -.11779 & .14275 & -.39947 & .16390 \\
\hline \multirow{2}{*}{$\begin{array}{l}\text { S4: GST has } \\
\text { ease the doing } \\
\text { business in India }\end{array}$} & $\begin{array}{l}\text { Equal variances } \\
\text { assumed }\end{array}$ & .004 & .949 & .951 & 198 & .343 & .14663 & .15424 & -.15753 & .45080 \\
\hline & $\begin{array}{l}\text { Equal variances } \\
\text { not assumed }\end{array}$ & & & .947 & 191.477 & .345 & .14663 & .15489 & -.15888 & .45215 \\
\hline \multirow{2}{*}{$\begin{array}{l}\text { S5: GST has } \\
\text { reduced the } \\
\text { material costs }\end{array}$} & $\begin{array}{l}\text { Equal variances } \\
\text { assumed }\end{array}$ & 9.768 & .002 & -2.658 & 198 & .009 & -.47756 & .17970 & -.83193 & -.12320 \\
\hline & $\begin{array}{l}\text { Equal variances } \\
\text { not assumed }\end{array}$ & & & -2.638 & 184.824 & .009 & -.47756 & .18106 & -.83478 & -.12035 \\
\hline \multirow{2}{*}{$\begin{array}{l}\text { S6: GST's } \\
\text { implementation } \\
\text { will expand the } \\
\text { market of your } \\
\text { business }\end{array}$} & $\begin{array}{l}\text { Equal variances } \\
\text { assumed }\end{array}$ & .283 & .595 & -3.129 & 198 & .002 & -.46955 & .15006 & -.76547 & -.17363 \\
\hline & $\begin{array}{l}\text { Equal variances } \\
\text { not assumed }\end{array}$ & & & -3.128 & 196.375 & .002 & -.46955 & .15012 & -.76561 & -.17349 \\
\hline \multirow{2}{*}{$\begin{array}{l}\text { S7: GST will } \\
\text { boost the } \\
\text { mission of } \\
\text { "Make in India" } \\
\text { campaign } \\
\end{array}$} & $\begin{array}{l}\text { Equal variances } \\
\text { assumed }\end{array}$ & 2.214 & .138 & -2.038 & 198 & .043 & -.24279 & .11912 & -.47770 & -.00788 \\
\hline & $\begin{array}{l}\text { Equal variances } \\
\text { not assumed }\end{array}$ & & & -2.043 & 197.939 & .042 & -.24279 & .11882 & -.47710 & -.00847 \\
\hline \multirow{2}{*}{$\begin{array}{l}\text { S8: GST } \\
\text { facilitates the } \\
\text { ease in } \\
\text { compliance in } \\
\text { compare of } \\
\text { previous } \\
\text { indirect tax } \\
\text { regime }\end{array}$} & $\begin{array}{l}\text { Equal variances } \\
\text { assumed }\end{array}$ & .002 & .961 & -3.433 & 198 & .001 & -.70593 & .20562 & $\begin{array}{c}- \\
1.11142 \\
\end{array}$ & -.30044 \\
\hline & $\begin{array}{l}\text { Equal variances } \\
\text { not assumed }\end{array}$ & & & -3.434 & 196.945 & .001 & -.70593 & .20556 & $\begin{array}{c}- \\
1.11131\end{array}$ & -.30055 \\
\hline \multirow{2}{*}{$\begin{array}{l}\text { S9: GST } \\
\text { improved the } \\
\text { transparency in } \\
\text { taxation system } \\
\text { and prices } \\
\end{array}$} & $\begin{array}{l}\text { Equal variances } \\
\text { assumed }\end{array}$ & 3.832 & .052 & -.190 & 198 & .849 & -.03526 & .18525 & -.40058 & .33007 \\
\hline & $\begin{array}{l}\text { Equal variances } \\
\text { not assumed }\end{array}$ & & & -.189 & 186.378 & .850 & -.03526 & .18653 & -.40324 & .33272 \\
\hline \multirow{2}{*}{$\begin{array}{l}\text { S10: GST } \\
\text { transformed the } \\
\text { Indian economy } \\
\text { as a common } \\
\text { economic } \\
\text { market } \\
\end{array}$} & $\begin{array}{l}\text { Equal variances } \\
\text { assumed }\end{array}$ & .000 & .998 & .534 & 198 & .594 & .06010 & .11260 & -.16195 & .28215 \\
\hline & $\begin{array}{l}\text { Equal variances } \\
\text { not assumed }\end{array}$ & & & .534 & 197.064 & .594 & .06010 & .11255 & -.16186 & .28205 \\
\hline \multirow[b]{2}{*}{$\begin{array}{l}\text { S11: GST will } \\
\text { give the } \\
\text { managerial } \\
\text { benefits due to } \\
\text { proper } \\
\text { accounting } \\
\text { record } \\
\text { maintenance for } \\
\text { legal } \\
\text { compliances }\end{array}$} & $\begin{array}{l}\text { Equal variances } \\
\text { assumed }\end{array}$ & 31.731 & .000 & -1.623 & 198 & .106 & -.25881 & .15950 & -.57335 & .05572 \\
\hline & $\begin{array}{l}\text { Equal variances } \\
\text { not assumed }\end{array}$ & & & -1.592 & 152.918 & .113 & -.25881 & .16255 & -.57995 & .06232 \\
\hline \multirow{2}{*}{$\begin{array}{l}\text { S12: GST will } \\
\text { give the benefits } \\
\text { in long run }\end{array}$} & $\begin{array}{l}\text { Equal variances } \\
\text { assumed }\end{array}$ & 5.755 & .017 & -.357 & 198 & .721 & -.03926 & .10985 & -.25589 & .17737 \\
\hline & $\begin{array}{l}\text { Equal variances } \\
\text { not assumed }\end{array}$ & & & -.355 & 188.064 & .723 & -.03926 & .11052 & -.25728 & .17875 \\
\hline \multirow{2}{*}{$\begin{array}{l}\text { S13: GST will } \\
\text { broaden the tax } \\
\text { base }\end{array}$} & $\begin{array}{l}\text { Equal variances } \\
\text { assumed }\end{array}$ & 3.543 & .061 & 2.172 & 198 & .031 & .30609 & .14094 & .02815 & .58403 \\
\hline & $\begin{array}{l}\text { Equal variances } \\
\text { not assumed }\end{array}$ & & & 2.150 & 178.788 & .033 & .30609 & .14236 & .02516 & .58702 \\
\hline $\begin{array}{l}\text { S14: GST will } \\
\text { improve the }\end{array}$ & $\begin{array}{l}\text { Equal variances } \\
\text { assumed }\end{array}$ & 1.194 & .276 & -1.767 & 198 & .079 & -.13862 & .07845 & -.29333 & .01609 \\
\hline
\end{tabular}




\begin{tabular}{|c|c|c|c|c|c|c|c|c|c|c|}
\hline $\begin{array}{l}\text { exports of the } \\
\text { country }\end{array}$ & $\begin{array}{l}\text { Equal variances } \\
\text { not assumed }\end{array}$ & & & -1.766 & 196.397 & .079 & -.13862 & .07848 & -.29340 & .01616 \\
\hline \multirow{2}{*}{$\begin{array}{l}\text { S15: GST is } \\
\text { complex to } \\
\text { understand }\end{array}$} & $\begin{array}{l}\text { Equal variances } \\
\text { assumed }\end{array}$ & 5.270 & .023 & -.293 & 198 & .770 & -.02885 & .09851 & -.22310 & .16541 \\
\hline & $\begin{array}{l}\text { Equal variances } \\
\text { not assumed }\end{array}$ & & & -.289 & 165.305 & .773 & -.02885 & .09998 & -.22626 & .16856 \\
\hline \multirow{2}{*}{$\begin{array}{l}\text { S16: GST has } \\
\text { increased the } \\
\text { inflation in } \\
\text { country }\end{array}$} & $\begin{array}{l}\text { Equal variances } \\
\text { assumed }\end{array}$ & 1.821 & .179 & .141 & 198 & .888 & .02163 & .15301 & -.28010 & .32337 \\
\hline & $\begin{array}{l}\text { Equal variances } \\
\text { not assumed }\end{array}$ & & & .142 & 197.971 & .887 & .02163 & .15244 & -.27898 & .32225 \\
\hline \multirow{2}{*}{$\begin{array}{l}\text { S17: GST has } \\
\text { increased the tax } \\
\text { burden on the } \\
\text { businessman }\end{array}$} & $\begin{array}{l}\text { Equal variances } \\
\text { assumed }\end{array}$ & 3.848 & .051 & -1.248 & 198 & .214 & -.13061 & .10466 & -.33700 & .07578 \\
\hline & $\begin{array}{l}\text { Equal variances } \\
\text { not assumed }\end{array}$ & & & -1.253 & 197.946 & .212 & -.13061 & .10425 & -.33620 & .07498 \\
\hline \multirow{2}{*}{$\begin{array}{l}\text { S18: GST has } \\
\text { increased the } \\
\text { compliance } \\
\text { costs }\end{array}$} & $\begin{array}{l}\text { Equal variances } \\
\text { assumed }\end{array}$ & 1.226 & .270 & -2.234 & 198 & .027 & -.27083 & .12126 & -.50996 & -.03171 \\
\hline & $\begin{array}{l}\text { Equal variances } \\
\text { not assumed }\end{array}$ & & & -2.225 & 191.838 & .027 & -.27083 & .12174 & -.51096 & -.03071 \\
\hline \multirow{2}{*}{$\begin{array}{l}\text { S19: In GST } \\
\text { return filing } \\
\text { formalities is } \\
\text { too tedious }\end{array}$} & $\begin{array}{l}\text { Equal variances } \\
\text { assumed }\end{array}$ & .031 & .860 & .423 & 198 & .673 & .04567 & .10800 & -.16731 & .25865 \\
\hline & $\begin{array}{l}\text { Equal variances } \\
\text { not assumed }\end{array}$ & & & .422 & 193.079 & .674 & .04567 & .10835 & -.16802 & .25937 \\
\hline \multirow{2}{*}{$\begin{array}{l}\text { S20: GST has } \\
\text { increased the } \\
\text { accounting } \\
\text { record } \\
\text { maintenance } \\
\text { work }\end{array}$} & $\begin{array}{l}\text { Equal variances } \\
\text { assumed }\end{array}$ & .315 & .575 & .432 & 198 & .666 & .04087 & .09450 & -.14549 & .22722 \\
\hline & $\begin{array}{l}\text { Equal variances } \\
\text { not assumed }\end{array}$ & & & .433 & 197.928 & .665 & .04087 & .09427 & -.14504 & .22677 \\
\hline \multirow{2}{*}{$\begin{array}{l}\text { S21: GST has } \\
\text { increased the } \\
\text { investment in } \\
\text { working capital }\end{array}$} & $\begin{array}{l}\text { Equal variances } \\
\text { assumed }\end{array}$ & 5.524 & .020 & 3.003 & 198 & .003 & .41587 & .13847 & .14280 & 68893 \\
\hline & $\begin{array}{l}\text { Equal variances } \\
\text { not assumed }\end{array}$ & & & 3.039 & 189.079 & .003 & .41587 & .13684 & .14593 & .68580 \\
\hline \multirow{2}{*}{$\begin{array}{l}\text { S22: The motto } \\
\text { of GST "one } \\
\text { nation and one } \\
\text { tax" is only a } \\
\text { illusion }\end{array}$} & $\begin{array}{l}\text { Equal variances } \\
\text { assumed }\end{array}$ & 3.694 & .056 & -.301 & 198 & .764 & -.02484 & .08248 & -.18750 & .13782 \\
\hline & $\begin{array}{l}\text { Equal variances } \\
\text { not assumed }\end{array}$ & & & -.298 & 176.493 & .766 & -.02484 & .08339 & -.18941 & .13973 \\
\hline \multirow{2}{*}{$\begin{array}{l}\text { S23: GSTN has } \\
\text { too many } \\
\text { technical } \\
\text { problems and } \\
\text { further difficult } \\
\text { the return filing } \\
\text { and getting ITC } \\
\text { on proper timing } \\
\end{array}$} & $\begin{array}{l}\text { Equal variances } \\
\text { assumed }\end{array}$ & 2.885 & .091 & 1.318 & 198 & .189 & .12099 & .09177 & -.05999 & 30197 \\
\hline & $\begin{array}{l}\text { Equal variances } \\
\text { not assumed }\end{array}$ & & & 1.324 & 197.850 & .187 & .12099 & .09138 & -.05921 & .30119 \\
\hline \multirow{2}{*}{$\begin{array}{l}\text { S24: GST is } \\
\text { affecting the } \\
\text { business very } \\
\text { badly }\end{array}$} & $\begin{array}{l}\text { Equal variances } \\
\text { assumed }\end{array}$ & 33.186 & .000 & 3.835 & 198 & .000 & .62660 & .16341 & .30436 & .94884 \\
\hline & $\begin{array}{l}\text { Equal variances } \\
\text { not assumed }\end{array}$ & & & 3.785 & 170.614 & .000 & .62660 & .16555 & .29981 & .95340 \\
\hline \multirow{2}{*}{$\begin{array}{l}\text { S25: GST will } \\
\text { be helpful in } \\
\text { overall } \\
\text { development of } \\
\text { economy }\end{array}$} & $\begin{array}{l}\text { Equal variances } \\
\text { assumed }\end{array}$ & .470 & .494 & .288 & 198 & .774 & .03446 & .11963 & -.20146 & .27037 \\
\hline & $\begin{array}{l}\text { Equal variances } \\
\text { not assumed }\end{array}$ & & & .288 & 197.633 & .773 & .03446 & .11945 & -.20111 & .27002 \\
\hline \multirow{2}{*}{$\begin{array}{l}\text { S26: GST has } \\
\text { improved the } \\
\text { profitability of } \\
\text { your business }\end{array}$} & $\begin{array}{l}\text { Equal variances } \\
\text { assumed }\end{array}$ & 25.653 & .000 & .681 & 198 & .497 & .11779 & .17291 & -.22319 & .45876 \\
\hline & $\begin{array}{l}\text { Equal variances } \\
\text { not assumed }\end{array}$ & & & .676 & 183.644 & .500 & .11779 & .17431 & -.22612 & .46169 \\
\hline
\end{tabular}

Source: field survey

After performing the independent sample T-test for checking the significant difference between the perceptions of traders and manufacturers towards these
26 variables, it is found from table 5 there is significant difference in perceptions of traders and manufacturers only for 8 variables i.e. GST has reduced the material cost $(\mathrm{t}=-2.638$ and $\mathrm{p}=.009)$, GST will expand the 
market of business ( $\mathrm{t}=-3.129$ and $\mathrm{p}=.002)$, GST will boost the mission of "Make in India" campaign ( $\mathrm{t}=-$ 2.038 and $\mathrm{p}=.043$ ), GST facilitates the ease in compliance in compare of previous indirect tax regime $(\mathrm{t}=-3.433$ and $\mathrm{p}=.001)$, GST will broaden the tax base $(\mathrm{t}=2.172$ and $\mathrm{p}=.031)$, GST has increased the compliance cost $(\mathrm{t}=-2.234$ and $\mathrm{p}=.027)$, GST has increased the investment in working capital $(\mathrm{t}=3.039$ and $\mathrm{p}=.003$ ) and GST is affecting business very badly $(\mathrm{t}=3.785$ and $\mathrm{p}=.000)$, hence for these 8 variables the null hypothesis viz-there is no significant difference between the perceptions of traders and manufacturers towards GST is rejected.

For the rest of the 18 variables it is found from the table 5 that there is no any significant difference between the perceptions of traders and manufacturers towards GST has reduced the cascading effect of taxation ( $\mathrm{t}=-.874$ and $\mathrm{p}=.383$ ), GST reduced the time in delivery of goods ( $\mathrm{t}=.655$ and $\mathrm{p}=.513)$, GST will check tax evasion ( $\mathrm{t}=-.825$ and $\mathrm{p}=.410)$, GST has ease the doing business in India ( $\mathrm{t}=.947$ and $\mathrm{p}=.345)$, GST has improved the transparency in taxation system and prices $(\mathrm{t}=-.190$ and $\mathrm{p}=.849)$, GST transformed the Indian economy as a common economic market $(\mathrm{t}=.534$ and $p=.594$ ), GST will give managerial benefits due to proper accounting records maintenance for legal compliances $(\mathrm{t}=-1.592$ and $\mathrm{p}=.113)$, GST will give benefits in long run ( $\mathrm{t}=-.355$ and $\mathrm{p}=.723)$, GST will improve the exports of the country $(\mathrm{t}=-1.769$ and $\mathrm{p}=0.079)$, GST is complex to understand $(\mathrm{t}=-.289$ and $\mathrm{p}=.773$ ), GST has increased the inflation in country $(\mathrm{t}=.141$ and $\mathrm{p}=.888)$, GST has increased the tax burden on businessmen ( $\mathrm{t}=-1.248$ and $\mathrm{p}=.214)$, In GST return filing formalities is too tedious $(\mathrm{t}=.423$ and $\mathrm{p}=.673)$, GST has increased the accounting record maintenance work ( $\mathrm{t}=.433$ and $\mathrm{p}=.665)$, the motto of GST "one nation and one tax" is only a illusion $(\mathrm{t}=-.301$ and $\mathrm{p}=.764$ ), GSTN has too many technical problems and further difficult the return filing and getting ITC on proper timing $(\mathrm{t}=1.318$ and $\mathrm{p}=.189)$, GST will be helpful in overall development of economy ( $\mathrm{t}=.288$ and $\mathrm{p}=.774$ ) and GST has improved the profitability of your business $(\mathrm{t}=.676$ and $\mathrm{p}=.50)$, hence for these 18 variable the null hypothesis viz-There is no significant difference between the perceptions of traders and manufacturers towards GST is not rejected.

Satisfaction of Traders and Manufacturers from GST's Implementation: This section explains the satisfaction of traders and manufacturers from GST's implementation and as table 4 shows the overall mean score of satisfaction for traders and manufacturers i.e. 3.645 , it means $73 \%$ of respondents are satisfied from GST's implementation. To check the statistical significant difference between the satisfaction score of traders and manufacturers for GST's implementation the following Hypothesis is developed:

Ho: There is no significant difference between the satisfaction of traders and manufacturers from GST.

Ha: There is significant difference between the satisfaction of traders and manufacturers form GST.

To check the significance of developed hypothesis, the independent sample t-test was conducted.

Table 6: Group statistics

\begin{tabular}{|l|c|c|c|c|c|}
\hline & Nature of business & N & Mean & $\begin{array}{c}\text { Std. } \\
\text { Deviation }\end{array}$ & $\begin{array}{c}\text { Std. Error } \\
\text { Mean }\end{array}$ \\
\hline $\begin{array}{l}\text { overall satisfaction } \\
\text { from GST }\end{array}$ & Manufacturing & 96 & 3.5938 & .80234 & .08189 \\
\cline { 2 - 6 } & Trading & 104 & 3.6923 & .73837 & .07240 \\
\hline
\end{tabular}

Source: field survey

Table 7: Independent samples test

\begin{tabular}{|c|c|c|c|c|c|c|c|c|c|c|}
\hline & \multicolumn{2}{|c|}{$\begin{array}{c}\text { Levene's Test } \\
\text { for Equality of } \\
\text { Variances }\end{array}$} & \multicolumn{7}{|c|}{ t-test for Equality of Means } \\
\hline & & \multirow[t]{2}{*}{$\mathrm{F}$} & \multirow[t]{2}{*}{ Sig. } & \multirow[t]{2}{*}{$\mathrm{T}$} & \multirow[t]{2}{*}{ df } & \multirow[t]{2}{*}{$\begin{array}{l}\text { Sig. (2- } \\
\text { tailed) }\end{array}$} & \multirow[t]{2}{*}{$\begin{array}{c}\text { Mean } \\
\text { Difference }\end{array}$} & \multirow[t]{2}{*}{$\begin{array}{l}\text { Std. Error } \\
\text { Difference }\end{array}$} & \multicolumn{2}{|c|}{$\begin{array}{l}\text { 95\% Confidence } \\
\text { Interval of the } \\
\text { Difference }\end{array}$} \\
\hline & & & & & & & & & Lower & Upper \\
\hline \multirow{2}{*}{$\begin{array}{l}\text { overall } \\
\text { satisfaction } \\
\text { from GST }\end{array}$} & $\begin{array}{l}\text { Equal variances } \\
\text { assumed }\end{array}$ & 1.576 & .211 & -.905 & 198 & .367 & -.09856 & .10894 & -.31339 & .11628 \\
\hline & $\begin{array}{l}\text { Equal variances } \\
\text { not assumed }\end{array}$ & & & -.902 & 192.873 & .368 & -.09856 & .10931 & -.31415 & .11703 \\
\hline
\end{tabular}

Source: field survey

As table 7 shows that there is no any significant difference between the satisfaction of traders and manufacturers from GST's implementation $(\mathrm{t}=-.905$ and $\mathrm{p}=.367$ ), hence the null hypothesis viz-There is no significant difference between the satisfaction of traders and manufacturers from GST's implementation is not rejected. 
This result shows that both group of traders and manufacturers from GST's implementation are satisfied.

\section{Conclusion}

The present study is an attempt to investigate the perceptions of traders and manufacturers towards GST, their satisfaction from GST's implementation and the significant differences between their perceptions and satisfaction. It has been found in this study most of the respondents were agree with the proposed benefits of GST such as it will benefit in long run, it has transformed the Indian economy as a common economic market, it will give managerial benefits due to proper accounting record maintenance for legal compliances, it will boost the "Make in India" campaign, it has reduced the cascading effect of taxation, it will expand the market of business, it reduced the time in delivery of goods, it will broaden the tax base, it will improve the exports of country, it will ease the doing business in India, it will check the tax evasion, it will improve the transparency in taxation system and prices and it will be helpful in overall development of economy. But the respondents were also agree that GST has various challenges like it is very complex to understand, GSTN has too many technical error, tedious return filing formalities, increased accounting maintenance work, increased compliance costs, motto of "one nation and one tax" is only a illusion (Singhvi, S. 2017), increased inflation, increased investment in working capital and increased the tax burden on businessmen. This study suggests that government should make training and awareness program to make the people more understandable about GST, improve the digital infrastructure in economy, reduce the return filing formalities, bring all the goods and services in one tax structure which remain to come such as petrol, diesel and alcohol, to check the tax evasion charge the heavy penalties from tax evaders and try to reduce the tax burden on small businesses.

\section{References}

1. Barhate, G. H. An Analytical Study of Awareness and Perception towards GST amongst Traders in Rural Areas. International Research Journal of Engineering and Technology. 2017;4(5):1133-1142.

2. Breen, J., Bergin-Seers, S., Roberts, I. \& Sims, R. The impact of introduction of GST on small businesses in Australia. Asian review of accounting. 2002;10(1):89104.

3. Huang, A. \& Liu, B. (2009). The Goods and Services tax (GST) and Bank Mortgage Costs: Empirical Evidence. Griffith Business School Discussion paper finance No 2009-2014

4. Kumar Aggarwal, M. People perception about GST: Empirical study. Kaav International journal of economics, commerce and Business management. 2017;4(3):1-6.

5. Mohamad Ali Roshidi Ahmad, Z. I. (2016). Awareness and Perception of Taxpayers towards Goods and Service Tax (GST) Implementation. International Journal of
Academic Research in Business and Social Sciences. 7593.

6. Padmashree D.Y. (2010). Impact of Sales Tax, Vat \&GST on the Profitability of Organizations. Patil University, Department of Business Management, Navi Mumbai. June 2010.

7. Rametse N., \& Pope, J., (2012). Start up tax compliance cost of GST: Empirical evidence from Western Australian Small Businesses, Article in Australian Tax Forum, 408-441.

8. Singhvi, S. One nation one tax-Challenges Ahead. Inspira-journal of Modern Management \& entrepreneurship. 2017;7(4):233-236.

9. Spiro, S, P. Evidence of a Post-GST increase in the underground economy. Canadian Tax Journal/Revue Fiscale Canadienne. 1993;41(2):247-258.

10. Zainol Anwar, F. \& Soon, T. (2016). GST: The impact, opportunities and challenges for Malaysian SMEs and experiences faced by other knowledge-based economy.

11. Chouhan, V. (2017). Measuring Awareness about Implementation of GST: A Survey of Small Business Owners of Rajasthan. Pacific Business Review International. 2017;9(8):116-125. 